\title{
Factors Affecting the Implementation of Effective Public Procurement Audit in Ethiopia: The Case of Federal Public Procurement and Property Administration Agency
}

Review Article

Tariku Burka Bedasso ${ }^{1} \&$ Baynesagn Asfaw $(\mathrm{PhD})^{2}$

${ }^{1,2}$ College of Finance, Management and Development, Dept. of Public Procurement and Asset Management, Ethiopian Civil Service University, Ethiopia.

\section{Corresponding Author}

Author Email:

tarikuburka9@gmail.com

\section{INTRODUCTION}

This study examined the factors affecting implementation of effective public procurement audit in Federal Public Procurement and Property Administration Agency of Ethiopia. The factors in this study conceived as the independent variables included of public procurement legal and regulatory framework, auditor's competence, organizational freedom, record management
Abstract: The study examined the factors affecting the effective implementation of public procurement auditing, in federal public procurement agency of Ethiopia. The general objective of this study was to assess the factors affecting the effective public procurement auditing in the Federal public procurement and property administration agency of Ethiopia in undertaking its mandate of procurement auditing federal public sector organizations, to ascertain the implementation of public procurement auditing in ensuring public accountability and promote better transparency in the use of public funds for procurement. A descriptive survey research design was adopted using quantitative methods and used close ended questionnaires as a data collection instrument. The study targeted 117 respondents but 101 returned the survey questionnaire, indicating a response rate of 86 per cent. Purposive and stratified sampling techniques were used to select respondents. Data was then analyzed on quantitative basis using Pearson's correlation, multiple linear regression analysis and descriptive statistics. The researcher found that there is strongly significant positive relationship among public procurement legal and regulatory framework, auditor's competence, organizational independence, the auditee's record management systems and the effective public procurement auditing in the Federal public procurement and property administration agency. The study recommended that FPPPAA should improve the legal framework of public procurement, the auditor's competence and the Ethiopian legislative body should give more attention for the revision of the over-sighting body organizational structure for implementation of the effective public procurement auditing. The study focused different major areas of organizational structure and the scenario indicates the necessity of further research in this area.

Keywords: Effective public procurement auditing, public procurement legal and regulatory framework, auditor's competence, organizational independence, record management system.

system while effective implementation as the dependent variable was measured in terms of increased public accountability and improved transparency.

An implementation of effective public procurement auditing reduces the dangers inherent in a principal agent relationship. The principal relies on the auditor to provide objective and an independent evaluation of the compliance of the agent's performance and to report on whether the agent uses the resources in accordance with the principal's wishes (Goodson, Kenneth and Lapointe, 2012).

This paper includes background to the study, problem statement, purpose of the study, objectives of the study, research questions, research hypothesis, scope of the study (including content scope and geographical scope). The paper also looks at the significance of the study, operational definition of key terms and, finally, the organization of the study. 
The important developments in the history of auditing in Ethiopia took place in the 1960s. Firstly, the Commercial Code of Ethiopia was proclaimed in 1960 (Government of Ethiopia, 1960). This Code contains accounting and external auditing provisions, which still serve as the legal basis for financial reporting and external audit of companies (Argaw, 2000; Kinfu, 1970; Kinfu, Negash \& Merissa, 1981; World Bank, 2007). The code contains some requirements for financial accounting, reporting, and external auditing of companies that operate in Ethiopia. Limitations that possibly constrained the code's contribution to the development of accounting and auditing in the nation include that it does not: (a) specify the accounting standards to be followed in financial reporting; (b) define the qualifications of an auditor; (c) require compliance with professional standards on auditing; or (d) impose an audit requirement upon private limited companies with less than 20 members (World Bank, 2007).

The second development was the formation of the Office of the Auditor General (OAG) in 1961 by Proclamation 199/1961(Government of Ethiopia, 1961). This proclamation accorded the OAG greater authority than was provided in the 1944 proclamation that established the Audit Commission (Argaw, 2000; Kinfu, 1990). The proclamation has subsequently been revised three times, in 1979, 1987 and 1997. The 1997 version of the proclamation is the legal basis for external audit for government organizations in Ethiopia to date of writing.

Auditing, according to Abdolmohammadi and Thibodeau (2007), is a means of ascertaining whether established criteria have been complied with, through the collection and evaluation of sufficient evidence. Effective public procurement audit can therefore be explained as the process of ascertaining whether established public procurement criteria have been complied with and expected public procurement outcomes have been or would be achieved.

The history of public procurement auditing in Ethiopia does not go far from a decade. According to Brooks and Demissie (2009), during the Derg regime, the functions of public procurement were handled by the Ministry of Finance. Procurements were made centrally with the tendering committee having the responsibility to made decisions on procurements. The legislative framework governing the procurement system in the country was very poor that only a procurement manual was issued in 1981.

Though public procurement shares 60 percent of the total public spending, it hasn't been given due attention so far in the country (Dubale, 2014). Until recent years, over-sighting of public procurement has been the responsibility of a smaller unit (Department) within the Ministry of Finance and Economic Development. In recent years, however, it has been combined with the Property Administration Department and renamed as Public Procurement and Property Administration Agency (PPA).

In 2009 Federal Democratic Republic of Ethiopia has reestablished the Public Procurement and Property Administration Agency, directly responsible to the ministry of Finance and Economic Development(MOFED), in Proclamation No. 649/2009 to regulate the Federal public procurement and property administration have to comply with the following principles: ensure value for money in the use of public fund for procurement; non discrimination among candidates on grounds of nationality or any other criteria not having to do with their qualification, except in cases of preference specifically provided for in this Proclamation; transparency and fairness of the criteria on the 
basis of which decisions are given in public procurement as well as of decisions in each procurement. On this Proclamation Article 15/9, the Agency has granted to conduct public procurement audit to ensure that procurement and property administration activities of public bodies are in accordance with this Proclamation and other documents governing public procurement and property administration.

The Ethiopian Public Procurement and Property Administration Agency, further, has four main departments among which is the Complaints Review and Resolution Department. The Agency has a committee to receive complaints from candidates or bidders. According to CPAR report (2010), it is difficult for the committee to act independently as far as it is dependent on MoFED. First, members of the Committee are selected by government in such a way that the Ministry of Finance and Economic Development will be the chair and Public Procurement and Property Administration Agency, Public Enterprises, Public Bodies, the Ethiopian Chamber of Commerce and Sector Associations (ECCSA) all serving as members of the Committee.

Apart from the Proclamation, there is also the Federal Government Public Procurement Directive issued by the Minister of Finance and Economic Development that entered into force on 8th day of June 2010, which defines responsibilities of heads of public bodies in making arrangements necessary for procurement audit or inspection to be conducted by the Public Procurement and Property Administration Agency (hereinafter called the Agency) in respect of the execution of procurements by the Public Body and taking appropriate corrective measures in accordance with the instruction given by the Agency based on the findings of the procurement audit and notifying the Agency of such measures (FPPPA, Ethiopia audit manual, 2011).

According to (PPA report, 2009), “...the most obvious challenge to the procurement audit function is the fact that there is a lack of procurement capability vested in the control units. Thus, while the Auditor Department is keen to become involved in the procurement sector, it lacks qualified staff with knowledge of procurement. The same problems apply to the internal control units where there is a shortage of procurement professionals and even though an audit function has been established within PPA. This function is still constrained and needs to build further capacity in order to function as an effective control mechanism."

To fulfill the procurement audit objectives an auditor is expected to plan and design an audit approach, test controls and transactions, perform analytical procedures and evaluate the procurement process compliance with the procurement laws, rules and regulation and complete the audit and issue an audit report. In addition, professional auditing standards and ethical standards must also be followed to conduct effective audit (FPPPAA audit manual, 2011).

To ensure whether procurement has been done accountably, public organizations required to establish a clear procurement compliance audit. Thus, the International Federation of Accountants (IFAC) sets highly-quality auditing and assurance standards to enhance the consistency of auditing practice throughout the world thereby strengthening public confidence in the global auditing and assurance profession. According to Manasseh (2007), the government auditors examine procurement operations and documents, pursuant to the appointment terms and in compliance with relevant statutory requirements. Availability of sound legal framework offers boundaries and benchmarks against which audit is undertaken objectively. 
Effective implementation of public procurement audit ensures whether the public procuring entities accomplish best value for money and probity, and by so doing secure public confidence (New Zealand Controller and Auditor-General, 2009). To ensure that public procurement performs as expected one cannot overlook the essence of an effective audit system. Public procurement entities must stick to all relevant rules and regulations governing procurement activities in order to be able to achieve enhanced productivity, efficiency, effective utilization of resources and a healthy government budget (Nketia-Asante, 2012).

The Public Procurement and Property Administration Agency of the Federal Government of Ethiopia (2011) views public procurement audit as one of the decisive means of better administration of public funds and for the achievement of a public entity's mission and vision; safeguarding public funds against abuse, waste and lost; ensuring that procurement entities comply with legislative and regulatory provisions governing public procurement and; making available procurement information to relevant agencies and the general public in a timely manner to enhance accountability. On the contrary, evidences showed that the rate of non-compliance on public procurement practices of public institutions increasing from year to year (FPPPA, audit directorate report, 2013; 2014; 2015; 2016; 2017). Besides, the Ethiopian Public Procurement and Property Disposal Complaint Hearing Board, (PPPDCHB), report in the years 2010/11 through 2014/15 implied in the area of public procurement, there is a trend showing an increase in the number of complaints brought before the Procurement and Property Disposal Complaint Hearing Board, for which miss-conduct on the part of government officials is found to be one of the leading reasons why bid award decisions are reversed by the Board. The number of complaints lodged with the PPPDCHB, from 35 in the years 2010/11 raised to 117 in the year 2014/15. This evidence shows that complaints against public procurement are increasing at increasing rate.

Numerous studies have been done so far with regard to the government auditing effectiveness, quality and efficiency on several countries based on their organizational structure and legislative power granted by the constitution. However, to the best of my knowledge, no study has been done on factors that affect the effectiveness of public procurement auditing in Ethiopia in terms of public procurement legal and regulatory framework, auditor's competence, auditors independence, record management system and resource constraints. Despite the availability of similar studies in other countries, their findings may not be generalized to Ethiopia owing to differences in demographic, economic, political and other factors. This study therefore intends to fill the existing gap by answering the question: what are the factors that affect the effectiveness of public procurement audit in Ethiopia.

This study aims to identify the factors affecting the implementation of effective public procurement auditing in Federal Public Procurement and Property Administration Agency of Ethiopia. To fill the existing gap and since public procurement audit hindrances have potential negative impacts on the performance of public procurement function, elimination of these challenges will go a long way to aid the proper functioning of public procurement system in Ethiopia. Judicious utilization of resources of countries is one of the convinced ways of placing these countries on the path of national development. 
OBJECTIVES OF THE STUDY

The general objective of this study is to assess the factors affecting the implementation of effective public procurement auditing in the Federal public procurement and property administration agency of Ethiopia.

\section{HYPOTHESES OF THE STUDY}

Several statements of supposition can be made in view of the factors affecting the effective public procurement audit in the federal government of Ethiopia, the case of FPPPAA. In light of the above research objective the study has designed the following directional hypothesis.

H1: Public procurement laws and regulatory framework affect the implementation of effective public procurement auditing in FPPPAA, Ethiopia.

H2: Public procurement auditor's competence affects the implementation of effective public procurement auditing in FPPPAA, Ethiopia.

H3: Organizational independence affects the implementation of effective public procurement auditing in FPPPAA, Ethiopia.

H4: Public procurement records management system affects the implementation of effective public procurement auditing in FPPPAA, Ethiopia.

\section{REVIEWS OF RELATED LITERETURE}

This paper critically reviews the literature on effective procurement auditing systems highlighting sections regarding to the various variables and their possible or observed effects on effective public procurement auditing systems. The paper also presented the conceptual framework of the study.

A theory includes a set of basic assumptions and axioms as the foundation and the body of knowledge. A theory is composed of logically interrelated, empirically verifiable prepositions. Theoretical framework provides the research the lens to view the world clearly (Camp, 2001). This section reviewed the agency, stewardship and inspired confidence theories which are related to this study.

\section{EFFECTIVE PUBLIC PROCUREMENT AUdIT}

Different authors were defined the term "effectiveness" as follows; for instance, Arena and Azzone (2009) defined effectiveness as "the capacity to obtain results that are consistent with targets". Dittenhofer (2001) "Effectiveness is the achievement of auditing goals and objectives using the factor measures provided for determining such factors". In Mihret and Yismaw, (2007) internal audit effectiveness is defined as "the extent to which an internal audit office meets its supposed objective or the extent to which it meets the intended outcome".

Empirical literature by Woolf (2002); Namusonge (2007); Manasseh (2007) concur that a public audit is considered effective if it accomplishes the intended results of fostering good governance and effective accountability in the management of public resources timely, with minimal cost, generates quality reports (showing control gaps and 
how to address them), prevents occurrence of fraud and embraces the use of information and communication technology.

According to FPPPAA audit manual 2010, to be effective, the procurement audit arrangements for public bodies should ensure that all public bodies partly of wholly financed by the Federal Government budget should be subject to the procurement audit by the Agency to ensure value for money in the use of public funds for procurement and promote better transparency and accountability. And that the Agency should fully independent in the conduct of the procurement audit, has sufficient authority to carry out the procurement audit in a manner that meets best practice in the audit of public fund, has adequate resources to carry out the procurement audit, has the right and obligation to report on the results of the procurement audit to the heads of public bodies concerned through the Head of the agency and meets relevant professional and ethical standards.

The mandate of the Agency's for procurement audit is derived from the Ethiopian Federal Government Procurement and Property Administration Proclamation No. 649/2009 and established under the Article 15.9 (Functions of the Agency) and Article 5.19 of the Directive. This unique position of trust places a responsibility on the agency to carry out its work in accordance with the highest professional standards. These standards provide a framework for the establishment of procedures and practices to be followed in the conduct of audit (FPPPAA audit manual, 2010). Public procurement Auditing Standards that lay down the basic standards that auditors are expected to meet in conducting their audits, put stress on the importance of independence and professional competence of staff; exercising due care; proper planning and supervision; reasonableness of criteria; sufficiency, reliability, and relevance of evidence to support conclusions; and fairness and completeness in reporting. As a result of adoption and application of these standards and values, the agency is believed to be able to play a more effective and enhanced role in promoting greater transparency, accountability and good governance in the public administration of federal government of Ethiopia (FPPPAA, 2010).

Besides, conduct of moral standards and ethical values would ensure a credible environment of professionalism, and earn trust, credibility and respect from the auditees. Code of Ethics for public procurement Auditors (FPPPAA, 2010), which is a comprehensive statement of the values and principles guiding the daily works of auditors, should be viewed as a necessary complement reinforcing the public procurement Auditing Standards in the discharge of auditing function. Any deviation or delinquency in the professional conduct or any improper conduct in their personal life places the integrity of auditors and the quality/validity of their audit work in an unfavorable setting, and may raise doubts about the reliability, effectiveness and competence of the FPPPAA audit, itself. The general principles of this Code are integrity, independence, objectivity and impartiality, competence, mandate, economy, efficiency, effectiveness of operations, political neutrality, substantiation, clear communication and professional confidentiality (FPPPAA audit manual, 2010).

\section{CONCEPTUAL FRAMEWORK}

Mugenda and Mugenda (2003) define a conceptual framework as a concise description of the phenomenon under study accompanied by a graphical or a visual depiction of the major variables of the study. Reichel and Ramey (1987) also define conceptual framework as a set of wide ideas and principles taken from relevant fields of inquiry 
and used to structure a subsequent presentation. It is research tools, intends to assist a study to develop awareness and understanding of the situation under examination and to communicate with the situation. It is used in research to outline possible courses of action or to present a preferred approach to an idea or thought. Figure 1, below explains dependent and independent variables of the study and how they relate to each other. The main objective of the study is to examine the factors affecting the public procurement auditing to become effective and enhanced role in promoting greater transparency, accountability and good governance in the public administration of federal government of Ethiopia. The independent variables identified are; legal and regulatory framework, auditor's competence, audit independence and Record Management system in the auditing function and the dependent variable is effective public procurement audit.

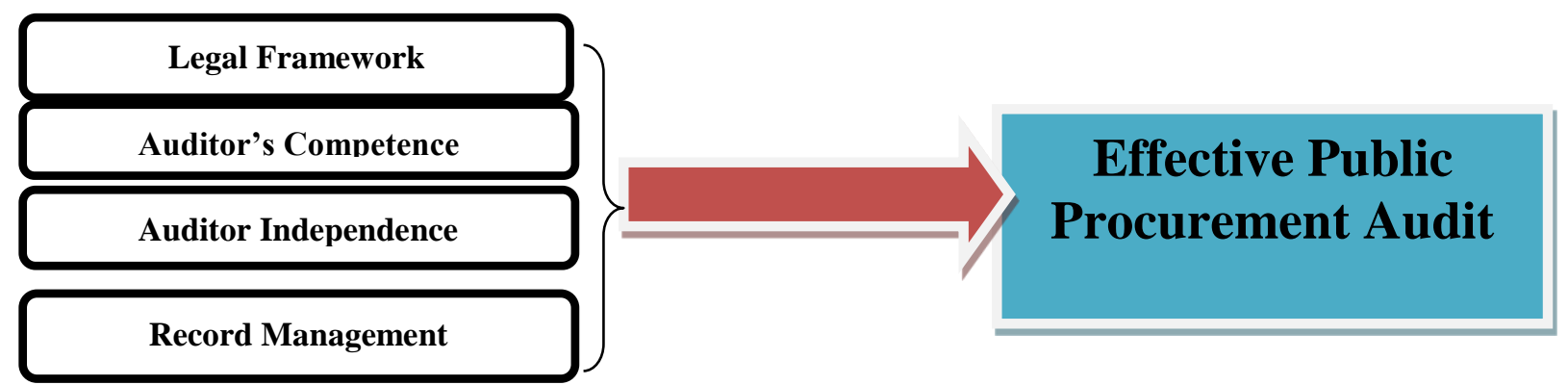

Source: Own author's, 2020

Figure 1: Conceptual framework for effective public procurement auditing

\section{RESEARCH METHODS}

The main objective of this study was to examine the factors affecting the effective public procurement auditing in Federal Public Procurement and Property Administration Agency. Hence, the appropriate research method is a descriptive survey research type, because it provides in determining the nature of units to be study along with the nature of the universe and also it helps in formulating relevant hypotheses along with the data which may be helpful in testing them, in addition, enable the generalized knowledge to get the existing situations of the federal public procurement audit service in order to ensure public accountability and transparency on the implementation of public procurement process in the federal public organizations.

The researcher adopted the five sampling steps of (Malhotra et al., 2006); these steps are closely interrelated and relevant to all aspects of the research. These are identifying target population, determining the sampling frame, select sampling techniques, determining the sample size and executing the sampling process.

\section{POPULATION AND SAMPLE SIZE}

The first one was to sample out the Ministries and Agencies and secondly the number of respondents within the selected Ministries and Agencies. According to the Federal Democratic Republic of Ethiopia Government portal (2020) currently there are 19 Ministries and 20 Agencies. Due to the difficulty of covering all the total existing public sector, the researcher obliged to minimize its study area by focusing only on 9 (six Ministries and three Agencies) were selected purposively from the total for they are highly budgeted and identified by government as 
development sector and also audited by federal public procurement and property administration agency annually, that are expected to be used as a representative of other sectors.

These organizations were selected purposively, because the use of purposive sampling enables the researcher to generate meaningful insights that help to gain a deeper understanding of the research phenomena by selecting the most informative participants that is satisfactory to its specific needs.

The target population for this study was 182 in total. 84 from Federal Public Procurement \& Property Administration Audit Directorate, Federal Public Procurement Administration Directorate, Federal Public Procurement Compliance Directorate, Federal Public Property Administration Directorate and Human Resource and General Service Directorate, which are directly or indirectly involved in procurement auditing process, by taking the data from Human Resource Directorate of FPPPAA and the remaining 98 from the selected federal government audetee institutions management staffs by taking recorded data from federal Procurement and property administration audit directorate.

The researcher has followed Zikmund \& Babin (2010) sampling technique by determining the sample proportion success and not success. Glenn (1992) stated assume that there is a large population but we do not know the variability in the proportion that will adopt the practice; therefore, assume $\mathrm{p}=0.5$ (maximum variability) and sample size determined at $95 \%$ confidence level.

Lewis and Thornhill (2012) state that the likely response rate shall be reasonable $50 \%$ or moderately high, while Patrick, (2003) referring Babie (1979), the return or success rate 50\% is 'adequate'; $60 \%$ response rate is 'good' and $70 \%$ rate or higher is 'very good'. Having this experience, for this research purpose confidence of successfully collect or return rate expected to

$70 \%$ and the remaining may be defected or non-response, and sample size determined at $95 \%$ confidence level.

Having this, the sample size has been determined with the help of the following formula of Kothari (2004).

$$
\mathrm{n}=\frac{\mathrm{Nz}^{2} \mathrm{pq}}{(\mathrm{N}-1) \mathrm{e}^{2}+\mathrm{z}^{2} \mathrm{pq}}
$$

Where,

$\mathbf{N}=$ the total population

$\mathbf{n}=$ sample size,

$\mathbf{p}=$ proportion of success $=70 \%$

$\mathbf{q}=$ proportion of fail $=1-p$ or $(30 \%)$

$\mathbf{z}=$ confidence level $=1.96$ from normal distribution table at $95 \%$ confidence level

$\mathbf{e}=$ standard error $=0.05$.

Therefore, by using the above parameters the researcher has obtained the sample size as follows: 
RESULTS

$\mathrm{n}=\frac{182 \times(1.96)^{2} 0.3 \times 0.7}{(182-1)(0.05)^{2}+(1.96)^{2} 0.3 \times 0.7}=\mathbf{1 1 7}$ Respondents were selected for the study

The main aim of this study was to examine the factors that affect the implementation of effective public procurement auditing in Federal government of Ethiopia. This paper presents the analysis and interpretation of the research findings obtained from the responded questionnaires. It begins with the description of the sample, presentation and interpretation of the results questionnaire response rate, followed by the descriptive statistics of the respondents' related questions; like the gender, age, field of study, level of education and work experience.

The study both descriptive statistic and regression analysis were used to analyze the data. The descriptive statistics utilized in this research was used to analyze the demographic data included frequency, percentages. Inferential analysis concerned with the various test of significance employed for testing hypothesis, normality, autocorrelation, multicollinearity, and helped to determine with what validity data can be said to indicate some conclusion(s). The data collected from the returned questionnaire were entered into SPSS (Statistical package for social science software) version 21 for analysis. The data was sorted to group questions according to applicable constructs under test. Finally a multiple regression analysis was performed by using all the discrete variables (dependent and independent) variables available in the dataset.

\section{THE REGRESSION RESULTS AND HYPOTHESIS TESTING}

The multiple liner regression result that were obtained by regressing the effective public procurement audit (EPPA) in minimizing noncompliance activities and enhancing public accountability on the practice of public procurement in the federal public organization on the better legal and regulatory framework of public procurement (PPLRFW), adequate auditor's competence (AC), organizational independence (OI), and better record management system (RMS) were analyze and reported. Finally, the hypothesis tests were undertaken based on the proposed hypothesis and the regression output results.

\section{REGRESSION RESULTS FOR EPPA}

In this study, multiple regression analysis was carried out to get the predictive value of the constructs considered. Since the model is developed in such a way that each construct is being affected by other constructs, it is necessary to carry out a separate regression analysis against each variable which are considered to be affected by other variables. This was basically made to determine the linear combination of the constructs. Regression of the implementation of effective public procurement audit (EPPA) on legal and regulatory framework (PPLRFW), auditor's competence (AC), and organizational independence (OI), and the regression results are presented on table 1,2 and 3.

Table 1: Regression Model summary

\begin{tabular}{|l|c|r|r|r|r|}
\hline Model & $\mathrm{R}$ & R Square & Adjusted R Square & Std. Error of the Estimate & Durbin-Watson \\
\hline 1 & $.815^{\mathrm{a}}$ & .665 & .651 & .39031 & 2.123 \\
\hline
\end{tabular}




\begin{tabular}{l} 
a. Predictors: (Constant), Record management system, Organizational independence, PP laws and \\
regulatory framework, Auditor's competence \\
\hline b. Dependent Variable: Effective public procurement auditing
\end{tabular}

Source: Survey result, 2020

Table 2: ANOVA Output SPSS

\begin{tabular}{|l|l|r|r|r|r|r|}
\hline \multicolumn{2}{|l|}{ Model } & \multicolumn{1}{|c|}{ Sum of Squares } & \multicolumn{1}{c|}{ df } & Mean Square & F & Sig. \\
\hline \multirow{2}{*}{1} & Regression & 29.015 & 4 & 7.254 & 47.616 & $.000^{\mathrm{b}}$ \\
\cline { 2 - 7 } & Residual & 14.625 & 96 & .152 & & \\
\cline { 2 - 7 } & Total & 43.640 & 100 & & & \\
\hline
\end{tabular}

Source: Survey result, 2020

Table 3: Coefficients Output SPSS

\begin{tabular}{|c|c|c|c|c|c|}
\hline \multirow[t]{2}{*}{ Model } & \multicolumn{2}{|c|}{ Unstandardized Coefficients } & \multirow[t]{2}{*}{ Standardized Coefficients } & \multirow[t]{2}{*}{$\mathrm{t}$} & \multirow[t]{2}{*}{ Sig. } \\
\hline & B & Std. Error & & & \\
\hline (Constant) & -1.043 & .264 & & -3.955 & .000 \\
\hline PPLRFW & .372 & .065 & .405 & 5.702 & .000 \\
\hline $\mathrm{AC}$ & .223 & .072 & .223 & 3.077 & .003 \\
\hline OI & 247 & .061 & .265 & 4.067 & .000 \\
\hline RMS & .231 & .075 & .210 & 3.089 & .003 \\
\hline
\end{tabular}

Source: Survey result, 2020

The regression result explores the main determinant factors of the effective public procurement audit by using the variables identified in the model. As indicated in the model summary (table 1) the appropriate indicators of the variable used to identify the determinant factors of EPPA were explored. That is, the value of $\mathrm{R}$ square used to identify how much of the variance in the dependent variable (EPPA) identify by the model. The larger the value of $\mathrm{R}$ square, the better the model is.

Table 1, the model summary depicted that the multiple $\mathrm{R}$ (correlation) value of 0.815 (81.5\%) indicated a highly positive relationship between the dependent and independent variables and, the overall contribution of the independent variables, legal and regulatory framework (PPLRFW), auditors competence (AC), organizational 
independence (OI), and better record management system (RMS) to the effective public procurement audit (EPPA) accounted for $66.5 \%(\mathrm{R} 2=0.665)$ of the variation in the EPPA, the rest $33.5 \%$ are other variables not included in this study. The result indicated a highly positive relationship between the dependent and independent variables, the value of $\mathrm{R}^{2}$ is 0.665 , revealing $66.5 \%$ variability in the effective public procurement auditing as a result of the independent variables. The value of adjusted $\mathrm{R} 2=0.651$ means that $65.1 \%$ of the changes in $\mathrm{Y}$ is explained by the independent variables. This adjusted measure provides a revised estimate, i.e. 65.1 per cent of the effective public procurement auditing is due to the fitted model. Therefore $\mathrm{R}^{2}$ in the model is at $66.5 \%$ which can be considered to moderate fit to the model. Table 2, presented the ANOVA report on the general significance of the model. As $\mathrm{p}$ is less than 0.05 , the model is significant by the values of F-statistics $(\mathrm{p}=0.000)$ and $(\mathrm{F}=47.616)$. Thus, the combination of the independent variables, legal and regulatory framework (PPLRFW), auditor's competence (AC), organizational independence (OI), and better record management system (RMS) significantly predict and are at best fit to model to predict the dependent variable (effective public procurement audit). Table 3 , provided the beta Coefficients that present the contributions or positive or negative relationship of each variable to the model. The $t$ and $p$ values showed the influence of the independent variables on the dependent variable. Beta sign of all the independent variables shows the positive effect of the predicting dependent variable. That means, any increase in the independent variables lead to increase in the dependent variable effective public procurement audit. From this, it is understandable that the legal and regulatory framework (PPLRFW) and organizational independence (OI) had the highest factor affecting on effective public procurement audit with comparing to the auditor's competence (AC) and the record management system (RMS) constructs. According to coefficient results, all predictors are positively related to the dependent variable and also based on the statistical significances of the independent variable over the dependent variable at 5\% level of significance, all of the independent variables are significantly affecting the EPPA at $(\mathrm{P}<0.05)$ level of confidence. Thus, the model for predicting perceived effective public procurement audit becomes:

\section{$E P P A=-0.043+0.372 P P L R F W+0.223 A C+0.247 O I+0.231 R M S+e$}

Where: $E P P A=$ Effective public procurement audit, $P P L R F W=$ public procurement laws and regulatory framework, $\mathrm{AC}=$ auditor's competence, $\mathrm{OI}=$ organizational independence, $\mathrm{RMS}=$ record management system .

The b-values (beta coefficient) tell us about the relationship between the outcome and each predictor. If the value is positive we can tell that there is a positive relationship between the predictor and the outcome, whereas a negative coefficient represents a negative relationship (Jensen, M.C., Black, F. and Scholes, M.S., 1972). For these data all predictors, except have positive b-values indicating positive relationships. So, there is a positive relationship between all the predictors, (PPLRFW, AC, IO and RMS) and an outcome effective public procurement audit (EPPA) as the value of beta coefficient is positive, (standardized regression coefficient $0.372,0.223,0.247$ and 0.231 at $\mathrm{p}<.05$, respectively).

\section{HYPOTHESIS TEST}

The regression analysis whose results are in the regression model provides a more comprehensive and accurate examination of the research hypothesis. Therefore, the regression results obtained from the model were utilized to 
test these hypotheses. The following hypotheses test were conducted based on the regression results of the public procurement laws and regulatory framework, auditor's competence, organizational independence and record management system obtained from the regression output.

\section{H1: PP Laws and regulatory framework factors affect the effective public procurement audit in FPPPAA}

Showing the strongly correlated relationship between the public procurement laws and regulatory framework with the effective public procurement audit, the positive beta sign and a statistically significant result of procurement laws and regulatory framework related with the public procurement regulation and over sighting $(\beta=0.372, t=$ 5.702, $\mathrm{P}<0.05)$ support the proposed hypothesis as acceptable. There is management support in terms of providing resources, conducting regular monitoring; improving the public procurement laws, providing enough facilities for the audit process with commitments to promote implementation of the audit recommendations for enhancing accountability and this in turn strongly supports the first proposed hypothesis (H1).

\section{H2: PP auditor's competence factors affect the effective public procurement audit in FPPPAA}

This hypothesis was also strongly supported by the regression result as results indicated significant relationship at $(\mathrm{P}<0.05)$. As shown in the table above, the coefficients of auditor's competence $(\beta=0.223)$ were positively related, statistically $(t=3.077, \rho<0.05)$ significantly related with the effective public procurement audit.

\section{H3: PP organizational independence factors affect the effective public procurement audit in FPPPAA}

As shown in the summery table above, the organizational independence, coefficients of $(\beta=0.247, t=4.067)$ were directly related with the effective audit and its statistical result $(\mathrm{P}<0.05)$ the regression output result has statistically indicated a significant relationship between the organizational independence and the implementation of the effective public procurement audit. Thus this hypothesis was strongly supported by the regression result as results indicated significant relationship at $(\mathrm{P}<0.05)$.

\section{H4: PP record management system factors affect the effective public procurement audit in FPPPAA}

The results of regression analysis revealed that the auditee public procurement records management system has a significant and direct effect on the implementation of effective public procurement audit $(\beta=0.231, p<0.05)$. Therefore, the Variable record management system has t count equal to 3.089 with a significance level of 0.003 (below 0.05 or $5 \%$ ). It is possible be concluded that the record management system in federal public organizations affect the implementation of effective public procurement audit by FPPPAA.

\section{DISCUSSION AND INTERPRETATION OF FINDINGS}

The purpose of this study was to examine the factors affecting effective public procurement audit using statistical analysis; both descriptive and inferential statistics. The study investigated the Ethiopian Federal Government public procurement and property administration agency which is a public procurement regulatory, to identify the factors affecting the implementation of effective public procurement auditing using a model developed for the analysis. Based on the regression model consisted of four core interrelated factors: laws and regulatory framework, 
auditor's competence, organizational independence and record management system in addition to other factors such as staff motivation, staff remuneration and salary level.

Professionalism among officials conducting oversight activities is also argued by scholars to generate better outcomes in terms of improving performance of the auditee (Isaksson \& Bigsten, 2012). The research observed from majority (90\%) of the audit staffs response on the questionnaires concerning on the trainings, remuneration and the level of satisfaction on their current salary, there was no adequate job related trainings for the public procurement auditors, there was no adequate remunerations in the agency and almost all of the auditors were not satisfied on their current salary. To ensure high-quality work, they need well-qualified, adequately remunerated staffs who are encouraged to improve continuously especially their subject-matter expertise (Cerullo, \& Cerullo, 2003). But the result indicated that public procurement agency didn't give attention for the improvement of auditor's capacity and retain the existing staffs with adequate salary and motivational scheme. This also leads to the agency implement the audit with low technical staff proficiency and exposed high staff turnover, which would limit its capacity to provide effective service to the public.

According to the regression output all these predictors were directly contributed for the effective implementation of public procurement auditing in Ethiopian federal public organizations. Therefore, the federal public procurement agency should give emphasis to use these factor variables to make their service delivery effective, efficient and economical throughout the auditee. Moreover the public procurement laws and regulatory framework and the organizational independence factors were the major determinants of EPPA in the federal public procurement and property administration agency followed by the auditor's competence and the record management system.

This study finds that the composite measure of public procurement laws and regulatory framework, the organizational independence, auditor's competence and the record management system accounts for $66.5 \%$ (R2 = 0.665 ) variance for the effective public procurement audit in minimizing noncompliance procurement practices and ensuring public accountability in the uses of public funds. That means, the effect of these four independent variables contributed for the dependent variable EPPA were 66.5\%, and the remaining 33.5\% were other variables that are not included in this study.

The final portion of this research aims to conclude the finding of the study focusing on the core determinants that have significant impacts to the effective public procurement audit and to provide recommendations based on the research findings of the study. These conclusions and recommendations are drawn from the findings of the study specifically related to the public procurement laws and regulatory framework given to the EPPA, the auditor's competence for the EPPA, the organizational independence of the EPPA, and the record management system in the federal public procurement and property administration agency.

Generally, the study concludes that even if the Constitution of Ethiopia provides for the independence of the FPPPAA, through proclamation 649/2001, there is more that needs to be done for the audit to be able to realize such independence authority in reality. The existing regulatory framework needs to be revised because currently the agency is rendered a watchdog institution without teeth to bite. An effective public sector audit activity strengthens governance by significantly increasing citizens' ability to hold their government accountable. The audit activity 
must be empowered to act with integrity and produce reliable services, although the specific means by which auditors achieve these goals vary.

\section{RECOMMENDATIONS}

In order to make effective public procurement audit, FPPPAA should consider the following points:

$>$ The Federal public procurement and property administration agency should consider on the convenient public procurement audit system as well as making brief and compressive public procurement law, policies, rules and regulations.

$>$ FPPPAA should publicize the audit findings to the public. An appropriate communication strategy should be adopted to communicate audit findings in easily understandable language to the general public. In addition, media whistle-blowing activities and civil participation in audits should be encouraged.

$>$ The FPPPAA audit must follow up with auditees to check whether they are following and implementing recommendations made. This follow up will reduce chances of further errors and mistakes. FPPPAA should have powers to take actions against fraud in financial data rather than merely reporting. Enforcement improves compliance, enforcement action and increased penalties lead to greater levels of compliance with laws.

$>$ The Federal public procurement and property administration agency should improve the remuneration and extreme benefits of public procurement auditors as this would enhance their efficiency and honesty in the discharge of their duties.

$>$ Finally; to recognize the full organizational independence FPPPAA should be directly responsible for Ethiopian house of representative and the legislative body should give more attention for the revision of the over-sighting body organizational structure to enhance public accountability.

\section{FUTURE RESEARCH IMPLICATIONS}

* The results will have important implications and is believed to be helpful for federal government of Ethiopia in particular and in Ethiopia in general. While this study has revealed some interesting results, one should be careful of its limitations related essentially to its sample size and scope of the study.

* Although the researcher believes that this study is deep, it is still believed that it can be further extended to include more respondents from externals (Office of Federal Audit General, other regional audit institutions) to make it more realistic and more reliable.

* Finally, due to different factors the researcher couldn't touch other dimensions of effective public procurement audit. Thus, further research needs to contain more desirable dimensions, in order to gain better insight.

* Therefore, future research should focus on these (33.5\%) other factors which affect effective implementation of the public procurement auditing like acts of Accounts Committee, application of computer-aided auditing techniques (CAATs) by auditors, Government policies, management support, and resource constraints among others. 


\section{REFERENCES}

Abbott, L. J., and S. Parker (1999), "Auditor quality and the activity and Independence of the audit committee", working paper, University of Memphis and Santa Clara University.

and Santa Clara University.

Abdolmohammadi, M.J. and Thibodeau, C.J. (2007) "Auditing”, in Kaliski, B.S.(ed.) Encyclopedia of Business and Finance.2nd edn. Detroit: Macmillan Reference, vol.1, pp. 42-45. Gale Virtual Reference Library Web [Online]. Available at:

http://go.galegroup.com.vlib.interchange.at/ps/i.do?id=GALE\%7CCX1552100029\&v=2.1\&u=wash89460\&it=r $\& p=G V R L \& s w=w \& a s i d=b 1 c 30 a c d f 2 d 1 f d 897382 e 642 a 4 f 6 a c f b$ (Accessed: 7 January 2017).

Achuora, J., Arasa, R., \& Ochiri, G.(2010). Precursors to Effectiveness of Public Procurement Audits for Constituency Development Funds (CDF) in Kenya. European Scientific Journal, November ed. Vol 8 No. 25 1857-7431.

Adams, J, Khan, Hafiz T.A., Rae (2007). Research Methods for Graduate Business and Social Science Students. New Delhi: SAGE. Available from: www.bookzz.org. [Dec 23 2017].

Argaw, L., 2000, 'The State of Internal Auditing in Ethiopia-The way Forward to Professionalism', paper presented to Inaugural Ceremony of the Institute of Internal Auditors-Ethiopian Paper, Addis Ababa, 16 December 2000.

Argaw, L., Desta, A. (1994), "Problems and prospects relating to audit practice in Ethiopia", Proceedings of the First Symposium on Accounting and Finance, Department of Accounting, Addis Ababa University, Addis Ababa, pp.132-55.

Brooks and Demissie, (2009), Public Procurement \& Property Administration Capacity Development Program, funded by the Canadian International Development Agency

C.R. Kothari, (2005). Research Methodology; Methods and Techniques. New Delhi: New Age International Publishers. Available from: www.bookzz.org .[Nov 23 2017].

C.R. Kothari, (2008). Research Methodology; Methods and Techniques. New Delhi: New Age International Publishers. Available from: www.bookzz.org. [On Oct 13 2017].

CCG. (2007). National Devolved Fund Report Instructional Structures and Reforms. Report No. 3 of April 2007 by Centre for Corporate Governance (CCG), Nairobi.

Cole, G.A (2008). Personnel and Human Resource Management. London: Bookpower

Columbia CTL (2015). Statistical Advantage of Stratified Random Sampling: Available from: http://ccnmtl.columbia.edu/projects/qmss/samples_and_sampling/types_of_sampling.html. [Dec 28, 2017].

Craswell, A. T., J. R. Francis, and S. L. Taylor, (1995), "Auditor brand name reputations and industry specialization", Journal of Accounting and Economics (20).

Creswel, J. (1999). Research Design- 4thedn. London: Cultural Policy,. Available from: https://www.researchgate.net/file.PostFileLoader.html?id=55eb95f16307d984de8. [Dec 17 2017].

DeAngelo, L. (1981), “Auditor size and audit quality”, Journal of Accounting and Economics 3 (3).

Dozzi, S. P., Abou Rizk, S. M. and Schroeder, S. L. (1996). 'Utility-Theory Model for Bid Mark-Up Decision'. Journal of Construction Engineering \& Management ASCE, vol.122 no. 2, pp.119-124. Available from: http://www.civil.uwaterloo.ca/tarek/MAUT.pdf. [October 23 2017].

Dubale, Y. (2014). Evaluation of procurement process at Addis Ababa Water and Sewerage Authority in Ethiopia. MBA thesis, Addis Ababa University.

Dunn, K. A., B. W. Mayhew, and S. G. Morsfield. (2000), “Auditor industry specialization and client disclosure quality". Working paper, Baruch College and University of Wisconsin.

Gelderman, J. C., Ghijsen, W. P. \& Brugman, J. M. (2006). Public procurement and EU tendering directivesexplaining non-compliance. International Journal of Public Sector Management, 19(7).

George, D., \& Mallery, P.( 2003). SPSS for Windows step by step, a simple guide and reference. 11.0 update 4th edn. Boston: Allyn \& Bacon. Available from https://en.wikipedia.org/wiki/Cronbach's_alpha [January 23 2016]. 
Goetz, A.M. \& R. Jenkins. 2001. "Hybrid Forms of Accountability: Citizen Engagement in Institutions of Public-Sector Oversight in India." Public Management Review: 3(3).

Kiawa, F. M. (2012) Accountability in Public Sector Procurement: A Case Study of the State Law Office. Unpublished MBA Thesis, University of Nairobi.

Kinfu, J. (1970), 'The Accounting provisions of the Commercial Code of Ethiopia', DBA thesis, Michigan State University.

Kinfu, J. (1990), "Accounting and auditing in Ethiopia: an historical perspective", in Pankhurst, R., Zekaria, A., Beyene, T. (Eds), Proceedings of the First National Conference of Ethiopian Studies, Institute of Ethiopian Studies, Addis Ababa University, Addis Ababa.

Kombo, D.K., and Tromp, D.L.A (2006). Proposal and Thesis Writing: An Introduction. Paulines Publications Africa.

Kombo, K., \& Tromp, A. (2011). Proposal and Thesis Writing, Pauline's, Nairobi. Available from: http://scholar.google.com/citations? user=odBfLH4AAAAJ\&hl=en.[Nov 25 2017].

Krivinsh, A. and Vilks, A. (2013) "Prevention of corruption in public procurement: importance of general legal principles", Jurisprudence, 20(1).

Manasseh, P.N. (2007). A text Book of Principles of Auditing. Nairobi: McMore Accounting Books.

Matendera, K. H. (2013). A survey of factors affecting public audit institutions performance: the case of Kenya national audit office. MBA Project, University of Nairobi.

Mugenda, M., \& Mugenda, G. (2003). Research Methods, Qualitative and Quantitative Approaches. Nairobi. ACTS press. Available at: www.bookzz.org.[October 19 2017].

Mugenda, O. M., \& Mugenda, A. G. (2003). Research Methods. Nairobi: Acts Press,. Available from: www.bookzz.org. [Dec 22 2016].

Neuman W.L. (2007). Basics of Social Research: Qualitative and Quantitative Approaches, 2nded. Boston: Pearson Education Inc,.

Saunders, M. L. (2007). Research Methods for Business Students, 4thedn. England: Pearson Education Limited. Available from: www.bookzz.org.[Dec 12 2017].

Simunic, D., and M. Stein, (1987), "Product differentiation in auditing: Auditor choice in the market for unseasoned new issues", Canadian Certified General Accountants' Research Foundation, Vancouver, British Columbia, Canada.

Sundgren, S., (1998), "Auditor choices and auditor reporting practices: evidence from Finnish small firms", European Accounting Review, 7(3).

The Federal Democratic Republic of Ethiopia, (2010) The Ethiopian Federal Government Procurement and Property Administration Manual

Wambui, (2015). "Factors affecting effectiveness of procurement auditing: the case of CDF

Wright, A., and S. Wright, (1997), "An examination of factors affecting the decision to waive audit adjustments", Journal of Accounting, Auditing, and Finance, Vol, 12. 